\title{
Effect of Selected Insecticides on Helicoverpa armigera Hubner (Lepidoptera: Noctuidae) on Tomato (Lycopersicon esculentum Miller) and Their Successful Management
}

\author{
Ghulam Abbas', Najamul Hassan', Muhammad Farhan', Ikramul Haq1, Haider Karar² \\ ${ }^{1}$ Pest Warning and Quality Control of Pesticides, Lahore, Pakistan \\ ${ }^{2}$ Entomological Research Sub-Station, Entomological Research Institute, Ayub Agricultural Research Institute, \\ Faisalabad, Pakistan \\ Email: drabbas18@gmail.com
}

Received 30 December 2014; accepted 20 January 2015; published 27 January 2015

Copyright (C) 2015 by authors and Scientific Research Publishing Inc.

This work is licensed under the Creative Commons Attribution International License (CC BY). http://creativecommons.org/licenses/by/4.0/

\section{Open Access}

\begin{abstract}
Helicoverpa armigera $\mathrm{H}$. is a polyphagous notorious pest of a number of economic crops including tomato. In tomato, it can reduce its yield as high as $70 \%$ due to fruit boring. Although some predators and parasitoids have been recorded in the field for their natural control, their manipulation to a successful crop management is still awaited. To overcome this pest, insecticides play a significant role in its effective crop management program globally. Tomato is an absolutely perishable commodity and needs the specified period required between the application, of conventional pesticides of organophosphate group, and consumption which can hardly be afforded. Therefore, nine insecticides from the new chemistries, which were relatively safer to human and environment, i.e. Coragen (chlorantraniliprole), steward (indoxacarb), Belt (flubendamide), Delegate (spintoram), Volium Flexy (chlorantraniliprole + thiamethaxim), Fipronil (grafter), Proclaim (emamectin benzoate), Pirate (chlofenapyr) and Lufenuron (lufenuron), were tested on tomato crop heavily infested by this pest in the farmers field in districts Lodhran and Bahawalpur (Pakistan) in the month of April 2014. The mortality was compared after 4, 7 and 10 days and treatments were compared with control as well with one another. The average maximum \% mortality, i.e. 89.36 and 85.09 of the pest, was observed with Volium Flexy, and Delegate also worked well even after 7 and 10 days. Similarly, the results on the basis of damaged fruits and percent loss of yield pointed out that Chlorantraniliprole, Flubendiamide and Indoxacarb had resulted better as compared with others, although the difference was statistically non significant. These new chemistry pesticides are suggested to be used at tomato crop against Helicoverpa armigera which are best fitted in the IPM program for the control of the pest.
\end{abstract}




\section{Keywords}

\section{Spintoram, Chlorantraniliprole, Helicoverpa armigera, Tomato, Pakistan}

\section{Introduction}

Helicoverpa armigera (Hubner) (Lepidoptera: Noctuidae) is a polyphagous pest, causing significant yield loss to field crops including tomato crop [1]. It is estimated that annual crop losses globally due to H. armigera alone are about 5 billion dollar [2]. In Pakistan, fruit losses due to H. armigera are 32\% - 35\% [3] and 53\% [4] in tomato fruit. Severity of the pest incidence can be judged from the fact that in Pakistan $80 \%$ of the total insecticides are used to overcome this pest [5]. Host plant resistance plays an important role in the minimization of losses to crops. Bt varieties are available in modern world, but there are reservations regarding adoption of $\mathrm{Bt}$ crops, particularly vegetables like tomato which is directly consumed in the food of human beings worldwide. Besides the hesitation in adoption of $\mathrm{Bt}$ tomato varieties, there are also some economic barriers. Since the most of the farming community in the developing countries is poor, storage facilities are lacking, and there is scarcity of skills and industry for transformation of raw material to value added products so marketing of such perishable commodities is uncertain and miserable therefore farmers cannot afford costly Bt varieties. In these circumstances there are few chances of resistant transgenic tomato varieties and the crop has to be tackled with alternate crop protection practices in future scenario as well.

Since alternate crop protection measures have very limited success stories, farmers have to depend upon the use of pesticides to overcome the pest quickly and effectively. However, the haphazard use of pesticides has resulted in numerous environmental and health problems [6]. Since tomato is an edible and extremely perishable commodity, the recommended period between the application of pesticide and marketing even consumption of the commodity is hardly observed. So there are fewer chances that farmers follow the ethics of plant protection and produce a product which can be fairly safe from health hazards. Therefore, it needs time to explore the efficacy of new chemistries which are relatively safer for the human health and environment, and share with farmers, extension workers and researchers the potential safe products and their efficacy against $H$. armigera which is worldwide regular pest of this crop. The safe and effective pesticides can be recommended on this important crop, as it is grown domestically in the pots and kitchen gardens as well as commercially in tunnels and fields all over the world. At the end of results, LD 50 of the products used in research trial has also been shared, so that the readers can compare the level of safety of the products. LD 50 stands for lethal dose of 50\% of the test animals (usually rats or rabbits) from which they die. It is a measure of safety of the product, particularly its safety to mammals.

\section{Materials and Methods}

The present study was carried out to determine the efficacy of different insecticides against the larval population density of Helicoverpa armigera on tomato in Farmer's field at two different locations Lodhran and Bahawalpur Districts (Punjab: Pakistan) during 2014. Bahawalpur is at 29.3955 latitude and 71.68 longitude [7] and Lodhran is its adjacent district across Sutluj river. The experiment was laid out in a Randomized Complete Block Design with ten treatments including a control with three replications. The plot size was $4.5 \mathrm{~m} \times 21 \mathrm{~m}$ and row to row distance was $60 \mathrm{~cm}$. The variety under trial was T-1359, provided by Syngenta (Pakistan) Ltd. Originally plant to plant distance was $45 \mathrm{~cm}$, but number of plants varied because of soil and irrigation factors. At some place multiple transplanting had succeeded where as in some places the single plants were not available after being dried. Similarly plant vigor was also variable. These factors were tried to homogenize by blocking and replication.

Nine insecticides, viz., Coragen (chlorantraniliprole), FMC United Pvt. Ltd., manufactured by Dupont, USA @ $100 \mathrm{ml}+15 \mathrm{ml}$ surfactant/acre, Steward (indoxacarb) FMC United Pvt. Ltd., @ 175 ml/acre, Belt (flubendiamide) Bayer Crop sciences @ 50 ml/acre, Delegate (spintoram) Ali Akbar enterprises Pvt. Ltd. Manufactured by Dow agro sciences, USA @ 60 g/acre, Volium Flexy (chlorantraniliprole + thiamethaxim) Syngenta (Pakistan) Ltd. @ 80 ml/acre, Grafter (fipronil) Agri Gold Pvt. Ltd manufactured by Vifam biotechnology Group, 
China@480 ml/acre, Proclaim (emamectin benzoate) Syngenta (Pakistan) Ltd. @ 200 ml/acre, Pirate (chlofenapyr) Swat Agro chemicals. Manufactured by BASF, USA, @ $320 \mathrm{ml} /$ acre and Lufenuron (lufenuron) Agri Gold Pvt. Ltd. manufactured by Jiangsu Flag chemicals, China @ 800 ml/acre. These are the dozes recommended by the manufacturer or distributer firms. All these insecticides are commonly available in the market and their trade names have been included in the article so that common men and less educated farmers can easily recognize it with its brand name which is usually advertised by the distributer firms through electronic and print media as well as wall other advertising tools. For spraying 100 litres of tubewell/hand pump water was used to make a spray able material in one acre $(43,560 \mathrm{sq} f \mathrm{ft}$ measures 1 acre, 1 hectare is equivalent to $2.47 \mathrm{acres})$. It may be added that usual ground water in this area contains $4-6$ ppm total dissolved salts (TDS) and an alkaline $\mathrm{pH}$ up to 8.7. The hand operated knapsack sprayer was used for spraying. All the insecticides were tried on a relatively ignored field of tomato crop having maximum population of Helicoverpa armigera, so that effect of the tested pesticides could be judged fairly. The maximum average temperature for the period under study (10 days) was recorded to be $33.38^{\circ} \mathrm{C}$ and $34.85^{\circ} \mathrm{C}$ for Lodhran and Bahawalpur respectively. The minimum average temperature for the same period was $21.63^{\circ} \mathrm{C}$ and $20.48^{\circ} \mathrm{C}$ for Lodhran and Bahawalpur respectively. Average relative humidity RH for morning and evening was 68.9, 23.4 and 70.5, 32.8 for Lodhran and Bahawalpur respectively. There was no rainfall during this period on both sites.

The criteria of selection of pesticides were that it should be new chemistry, is relatively safer to mamalia, safer to the environment and claims the mortality of $H$. armigera. The data on living larvae was recorded before spray and then after 4, 7 and 10 days post treatment. For the purpose of data collection, method of on sito count was adopted. The number of live larvae was noted on randomly selected 15 plants from each experimentalplot number of damaged fruits as well as total fruits were also noted. The yield losses were compared on qualitative bases, the fruit bored by $H$. armigera larva (caterpillar) was rendered as damaged because it has almost zero market value. It not only gets destroyed soon due to attack of saprophytic fungi but it also serves as the source of contamination and invasion of further fungal infection for healthy one packed in the cartoon or collected in the heap. The mortality of both the sites was aggregated and averaged for computing commutative average mortality of the pest. Then percent loss in yield has also been quantified through simple mathematical calculation percent of damaged fruits/total fruits, i.e.

$\%$ damaged fruits $=($ Damaged fruits/Total fruits $) \times 100$.

All the treatments were compared with control and one another to assess the performance of the treatment in uncontrolled field condition. The data were finally subjected to statistical analysis using Statistix version 8.1 and means were compared by using Tukey's HSD.

\section{Results}

\section{1. \% Mortality of Helicoverpa armigera 4 Days after Spray in District Lodhran}

The data on the effectiveness of various insecticides sprayed to overcome the Helicoverpa armigera revealed a highly significant difference among treatments in district Lodhran during $2014(\mathrm{~F}=472.14 ; \mathrm{df}=9,18 ; \mathrm{P}<0.01$; Table 1). The results showed that the insecticide Volium Flexy and Delegate gave statistically similar \% mortality of Helicoverpa armigera, i.e. 90 and 85.33 followed by Steward, belt, chlorfenpyr and Coragen having 74.33, $72.67 \%, 70.50 \%$ and $70 \%$ mortality of Helicoverpa armigera 4 days after spray. The insecticides Emamectin and Lufenuron gave statistically similar mortality i.e. $61.67 \%$ and $58.33 \%$. Minimum mortality of Helicoverpa armigera was recorded in fipronil having $52.33 \%$ mortality of Helicoverpa armigera.

\section{2. \% Mortality of Helicoverpa armigera 7 Days after Spray}

The data on the \% mortality of Helicoverpa armigera 7 days after sprayrevealed a highly significant difference among treatments in district Lodhran during $2014(\mathrm{~F}=435.83$; $\mathrm{df}=9,18 ; \mathrm{P}<0.01$; Table 1). The results showed that the insecticide Volium Flexy and Delegate gave similar \% mortality of Helicoverpa armigera, i.e. 89.33 and 86.67 statistically similar to Coragen, i.e. $83.33 \%$ followed by belt and Emamectin having 80 and $79.33 \%$ mortality of Helicoverpa armigera 7 days after spray. Steward having $76.67 \%$ mortality of Helicoverpa armigera. The insecticides chlorfenpyregave, i.e. 61.67 which is statistically similar to lufenuran having $58.33 \%$ followed by fipronil with 53.00 which is minimum mortality of Helicoverpa armigera. 
Table 1. Data regarding average \% mortality of Helicoverpa armigera on tomato in district lodhran.

\begin{tabular}{|c|c|c|c|c|c|}
\hline \multicolumn{2}{|c|}{ Insecticides } & \multirow[t]{2}{*}{$\begin{array}{c}\text { Dose } / 100 \\
\text { liter of water }\end{array}$} & \multicolumn{3}{|c|}{ AV. \% mortality of helicoverpa on tomato after } \\
\hline Trade name & Common name & & $\begin{array}{c}4 \text { days } \\
\text { Mean } \pm \text { SE }\end{array}$ & $\begin{array}{c}7 \text { days } \\
\text { Mean } \pm \text { SE }\end{array}$ & $\begin{array}{c}10 \text { days } \\
\text { Mean } \pm \text { SE }\end{array}$ \\
\hline Coragen & Chlorantraniliprole & $\begin{array}{c}100 \mathrm{ml}+15 \mathrm{~g} \\
\text { surfactant }\end{array}$ & $70.00 \pm 0.57^{\mathrm{b}}$ & $83.33 \pm 0.66^{\mathrm{ab}}$ & $51.92 \pm 1.23^{\mathrm{bc}}$ \\
\hline Steward $150 \mathrm{EC}$ & Indoxacarb & $175 \mathrm{ml}$ & $74.33 \pm 0.29^{\mathrm{b}}$ & $76.70 \pm 1.15^{\mathrm{c}}$ & $45.67 \pm 1.56^{\mathrm{c}}$ \\
\hline Belt 39.4 & Flubendiamide & $50 \mathrm{ml}$ & $72.67 \pm 0.62^{b}$ & $80.00 \pm 0.50^{\mathrm{bc}}$ & $49.00 \pm 0.87^{\mathrm{bc}}$ \\
\hline Delegate $25 \mathrm{EC}$ & Spintoram & $60 \mathrm{~g}$ & $85.33 \pm 0.81^{\mathrm{a}}$ & $86.67 \pm 0.71^{\mathrm{a}}$ & $62.67 \pm 0.56^{\mathrm{a}}$ \\
\hline $\begin{array}{l}\text { Volium Flexy } \\
300 \text { EC }\end{array}$ & $\begin{array}{l}\text { Thiamethaxim }+ \\
\text { chlorantraniliprole }\end{array}$ & $80 \mathrm{ml}$ & $90.00 \pm 0.89^{\mathrm{a}}$ & $89.33 \pm 0.31^{\mathrm{a}}$ & $55.00 \pm 1.35^{\mathrm{ab}}$ \\
\hline Fipronil & Fipronil & $480 \mathrm{ml}$ & $52.33 \pm 0.35^{\mathrm{d}}$ & $53.00 \pm 0.22^{\mathrm{e}}$ & $23.00 \pm 0.51^{\mathrm{d}}$ \\
\hline Emamectin $1.9 \mathrm{EC}$ & Emamectin benzoate & $200 \mathrm{ml}$ & $61.67 \pm 0.54^{c}$ & $79.33 \pm 0.76^{\mathrm{bc}}$ & $49.67 \pm 1.47^{\mathrm{bc}}$ \\
\hline Chlorofenapyr & Pirate & $320 \mathrm{ml}$ & $70.50 \pm 0.34^{\mathrm{b}}$ & $61.67 \pm 0.82^{\mathrm{d}}$ & $29.00 \pm 0.10^{\mathrm{d}}$ \\
\hline Lufenuron $5 \mathrm{EC}$ & Lufenuron & $800 \mathrm{ml}$ & $58.33 \pm 0.92^{\mathrm{c}}$ & $58.33 \pm 0.64^{\text {de }}$ & $27.00 \pm 0.59^{\mathrm{d}}$ \\
\hline & Control & & $3.85 \pm 0.26^{\mathrm{e}}$ & $5.33 \pm 0.19^{\mathrm{f}}$ & $4.33 \pm 0.27^{\mathrm{e}}$ \\
\hline & Tukey's HSD@5\% & & 5.60 & 6.09 & 9.05 \\
\hline & F-value & & 472.14 & 435.83 & 102.36 \\
\hline
\end{tabular}

Means sharing similar letters are not significantly different by Tukey's Test at $\mathrm{P}=0.05 ; \mathrm{HSD}=$ Honestly Significant Difference; Value * $=$ Significant at $\mathrm{P} \leq 0.05 ; * *=$ Significant at $\mathrm{P} \leq 0.01$.

\section{3. \% Mortality of Helicoverpa armigera 10 Days after Spray}

The data on the $\%$ mortality of Helicoverpa armigera 10 days after sprayrevealed a highly significant difference among treatments in district Lodhran during $2014(\mathrm{~F}=102.36$; $\mathrm{df}=9,18 ; \mathrm{P}<0.01$; Table 1). The results showed that the insecticide Delegate gave maximum mortality of Helicoverpa armigera, i.e. 62.67 which is statistically similar to Volium Flexy having 55.0\% followed by Coragen, Emamectin and belt having 51.92, 49.67 and $49.00 \%$ mortality of Helicoverpa armigera 10 days after spray. Steward having $45.67 \%$ mortality of Helicoverpa armigera. The minimum mortality was recorded from the insecticides chlorfenpyre, lufenuran and fipronil i.e. $29.0 \%, 27.0 \%$ and $23.0 \%$ mortality of Helicoverpa armigera.

\section{4. \% Mortality of Helicoverpa armigera 4 Days after Spray in District Bahawalpur}

The data on the effectiveness of various insecticides to overcome the Helicoverpa armigera revealed a highly significant difference $(\mathrm{F}=358.05 ; \mathrm{df}=9,18 ; \mathrm{P}<0.01$; Table 2$)$ among treatments in district Bahawalpur during 2014. The results showed that the insecticide Volium Flexy and Delegate gave statistically similar \% mortality of Helicoverpa armigera, i.e. 89.66 and 86.00 followed by Steward, Coragen and belt having 75.67\%, $72.00 \%, 72.00 \%$ mortality of Helicoverpa armigera 4 days after spray. The insecticide chlorfenpyr gave $68.67 \%$ mortality. Minimum mortality of Helicoverpa armigera was recorded in emamectin, fipronil and Lufenuron having $58.67 \%, 56.67 \%$ and $55.00 \%$ mortality of Helicoverpa armigera which are statistically similar.

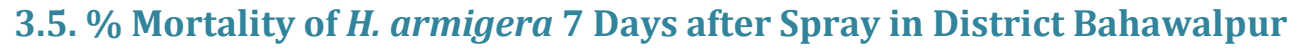

The data on the effectiveness of various insecticides to overcome the $H$. armigera revealed a highly significant difference $(\mathrm{P}<0.01$; Table 2) among treatments after 7 days post treatment in district Bahawalpur during 2014. The results showed that the insecticide Volium Flexy gave maximum mortality of H. armigera, i.e. $87.33 \%$ which is statistically similar to Delegate with $84.67 \%$ mortality of $H$. armigera followed by coregan, i.e. 81.33 . The insecticides belt and emamectin gave statistically similar mortality, i.e. $78 \%$ and $77.33 \%$ followed by Steward $74.67 \%$. The insecticide chlorfenpyr gave $59.67 \%$ mortality which is statistically similar to lufenuran having $56.33 \%$. Minimum mortality of $H$. armigera was recorded in fipronil having $51.00 \%$ mortality of $H$. armigera. 
Table 2. Data regarding average \% mortality of $H$. armigera on tomato in district Bahawalpur.

\begin{tabular}{|c|c|c|c|c|c|}
\hline \multicolumn{2}{|c|}{ Insecticides } & \multirow{2}{*}{$\begin{array}{c}\text { Dose } / 100 \\
\text { liter of water }\end{array}$} & \multicolumn{3}{|c|}{ AV. \% mortality of $h$. on tomato after } \\
\hline Trade name & Common name & & $\begin{array}{c}4 \text { days } \\
\text { Mean } \pm \text { SE }\end{array}$ & $\begin{array}{c}7 \text { days } \\
\text { Mean } \pm \text { SE }\end{array}$ & $\begin{array}{c}10 \text { days } \\
\text { Mean } \pm S E\end{array}$ \\
\hline Coragen & Chlorantraniliprole & $\begin{array}{c}100 \mathrm{ml}+15 \mathrm{~g} \\
\text { surfactant }\end{array}$ & $72.07 \pm 0.99^{\mathrm{bc}}$ & $81.33 \pm 0.66^{\mathrm{a}}$ & $48.63 \pm 1.01^{\mathrm{bc}}$ \\
\hline Steward $150 \mathrm{EC}$ & Indoxacarb & $175 \mathrm{ml}$ & $75.69 \pm 0.49^{\mathrm{b}}$ & $74.60 \pm 1.15^{\mathrm{d}}$ & $43.23 \pm 0.76^{\mathrm{c}}$ \\
\hline Belt 39.4 & Flubendiamide & $50 \mathrm{ml}$ & $72.37 \pm 1.10^{\mathrm{bc}}$ & $78.10 \pm 0.50^{\mathrm{cd}}$ & $46.38 \pm 0.87^{\mathrm{bc}}$ \\
\hline Delegate $25 \mathrm{EC}$ & Spintoram & $60 \mathrm{~g}$ & $87.03 \pm 1 / 43^{\mathrm{a}}$ & $84.65 \pm 0 / 71^{\mathrm{ab}}$ & $60.20 \pm 0.56^{\mathrm{a}}$ \\
\hline $\begin{array}{l}\text { Volium Flexy } \\
300 \text { EC }\end{array}$ & $\begin{array}{l}\text { Thiamethaxim }+ \\
\text { chlorantraniliprole }\end{array}$ & $80 \mathrm{ml}$ & $89.67 \pm 0.56^{\mathrm{a}}$ & $87.39 \pm 0.31^{\mathrm{a}}$ & $52.33 \pm 0.65^{\mathrm{b}}$ \\
\hline Fipronil & Fipronil & $480 \mathrm{ml}$ & $56.57 \pm 2.21^{\mathrm{d}}$ & $51.08 \pm 0.22^{\mathrm{f}}$ & $20.33 \pm 0.51^{\mathrm{d}}$ \\
\hline Emamectin $1.9 \mathrm{EC}$ & Emamectin benzoate & $200 \mathrm{ml}$ & $58.61 \pm 1.45^{\mathrm{d}}$ & $77.33 \pm 0.76^{\mathrm{cd}}$ & $47.00 \pm 0.78^{\mathrm{bc}}$ \\
\hline Chlorfenapyr & Pirate & $320 \mathrm{ml}$ & $68.68 \pm 1.71^{\mathrm{c}}$ & $59.66 \pm 0.82^{\mathrm{e}}$ & $26.33 \pm 0.10^{\mathrm{d}}$ \\
\hline \multirow[t]{4}{*}{ Lufenuron 5 EC } & Lufenuron & $800 \mathrm{ml}$ & $55.05 \pm 1.03^{\mathrm{d}}$ & $56.30 \pm 0.64^{\mathrm{ef}}$ & $24.33 \pm 0.58^{\mathrm{d}}$ \\
\hline & Control & & $4.31 \pm 0.10^{\mathrm{e}}$ & $5.00 \pm 0.36^{\mathrm{g}}$ & $4.67 \pm 0.18^{\mathrm{e}}$ \\
\hline & Tukey’s HSD@5\% & & 6.41 & 5.90 & 6.58 \\
\hline & F-value & & 358.05 & 447.55 & 179.52 \\
\hline
\end{tabular}

Means sharing similar letters are not significantly different by Tukey's Test at $\mathrm{P}=0.05 ; \mathrm{HSD}=$ Honestly Significant Difference; Value * $=$ Significant at $\mathrm{P} \leq 0.05 . * *=$ Significant at $\mathrm{P} \leq 0.01$.

\section{6. \% Mortality of $H$. armigera 7 Days after Spray in District Bahawalpur}

The data on the effectiveness of various insecticides to overcome the $H$. armigera revealed a highly significant difference $(\mathrm{P}<0.01$; Table 2) among treatments after 7 days post treatment in district Bahawalpur during 2014. The results showed that the insecticide Volium Flexy gave maximum mortality of H. armigera, i.e. 87.33\% which is statistically similar to Delegate with $84.67 \%$ mortality of $H$. armigera followed by coregan, i.e. 81.33 . The insecticides belt and emamectin gave statistically similar mortality, i.e. $78 \%$ and $77.33 \%$ followed by Steward $74.67 \%$. The insecticide chlorfenpyr gave $59.67 \%$ mortality which is statistically similar to lufenuran having $56.33 \%$. Minimum mortality of $H$. armigera was recorded in fipronil having $51.00 \%$ mortality of $H$. armigera.

\subsection{Cumulative Average \% Mortality of H. Armigera 4 Days after Spray in District Lodhran and Bahawalpur}

The data on the effectiveness of various insecticides to overcome the $H$. armigera revealed a highly significant difference $(\mathrm{P}<0.01$; Table 3 ) among treatments after 4 days after spray cumulative in districts Lodhran and Bahawalpur during 2014. The results showed that the insecticide Volium Flexy and Delegate gave maximum mortality of $H$. armigera, i.e. $89.83 \%$ and $85.67 \%$ followed by steward having $75 \%$ mortality which is statistically similar to belt and Coragen with $72.33 \%$ and $71 \%$ mortality of $H$. armigera statistically similar to chlorfenpyr having 59.58. The insecticides emamectin gave $60.17 \%$ mortality statistically similar to lufenuran, i.e. $56.67 \%$ followed by fipronil $54.50 \%$ mortality which is the lowest.

\subsection{Cumulative Average \% Mortality of $H$. armigera 7 Days after Spray in District Lodhran and Bahawalpur}

The data in the table revealed a highly significant difference ( $\mathrm{F}=444.15 ; \mathrm{df}=9,18 ; \mathrm{P}<0.01$; Table 3$)$ among treatments after 7 days after spray cumulative in districts Lodhran and Bahawalpur during 2014. The results showed that the insecticide Volium Flexy gave maximum mortality of $H$. armigera, i.e. 88.33 which is statistically similar to Delegate with $85.67 \%$ followed by Coragen having $82.33 \%$ mortality which is statistically similar to steward with $75.67 \%$ mortality of $H$. armigera. The insecticide chlorfenpyr gave $60.67 \%$ mortality which is statistically similar to lufenuran having $57.33 \%$ mortality followed by fipronil $52.00 \%$ mortality which is the lowest. 


\subsection{Comparisons on the Bases of Cumulative Fruit Losses by H. armigera 10 Days after Spray at Research Sites and their Comparisons with Control}

There was significant difference among treatments ( $\mathrm{P}$ value 0.0017$)$ on the bases of losses in fruit of tomato crop. The average number of the damaged fruit of tomato fruits in each treatment after 10 DAS is reflected as under in descending order. Anyhow, total loss in yield has also been indicated against each treatment in the next column.

The average percent yield loss has been provided against each pesticide correspondingly. It is evident from the results that control has maximum average population larvae 6.67 which is significantly different from Indaxacarb, flubendiamide and chlorantraniliprole having 1.0, 1.0 and 0.67 respectively (Table 4).

Table 3. Data regarding commutative average \% mortality of $H$. armigera on tomato in districts (Bahawalpur and Lodhran).

\begin{tabular}{|c|c|c|c|c|c|}
\hline \multicolumn{2}{|c|}{ Insecticides } & \multirow{2}{*}{$\begin{array}{c}\text { Dose } / 100 \\
\text { liter of water }\end{array}$} & \multicolumn{3}{|c|}{ AV. \% mortality of h. on tomato after } \\
\hline Trade name & Common name & & $\begin{array}{c}4 \text { days } \\
\text { Mean } \pm S E\end{array}$ & $\begin{array}{c}7 \text { days } \\
\text { Mean } \pm \text { SE }\end{array}$ & $\begin{array}{c}10 \text { days } \\
\text { Mean } \pm \text { SE }\end{array}$ \\
\hline Coragen & Chlorantraniliprole & $\begin{array}{c}100 \mathrm{ml}+15 \mathrm{~g} \\
\text { surfactant }\end{array}$ & $71.07 \pm 0.21^{\mathrm{bc}}$ & $82.23 \pm 1.99^{\mathrm{bc}}$ & $50.57 \pm 0.72^{\mathrm{bc}}$ \\
\hline Steward 150 EC & Indoxacarb & $175 \mathrm{ml}$ & $75.53 \pm 0.11^{b}$ & $75.65 \pm 3.45^{\mathrm{d}}$ & $44.23 \pm 0.68^{\mathrm{c}}$ \\
\hline Belt 39.4 & Flubendiamide & $50 \mathrm{ml}$ & $72.11 \pm 0.85^{\mathrm{bc}}$ & $79.3 \pm 1.49^{\mathrm{cd}}$ & $47.31 \pm 0.97^{\mathrm{bc}}$ \\
\hline Delegate $25 \mathrm{EC}$ & Spintoram & $60 \mathrm{~g}$ & $85.09 \pm 1.04^{\mathrm{a}}$ & $85.61 \pm 1.27^{\mathrm{ab}}$ & $61.07 \pm 0.36^{\mathrm{a}}$ \\
\hline $\begin{array}{l}\text { Volium Flexy } \\
300 \text { EC }\end{array}$ & $\begin{array}{l}\text { Thiamethaxim + } \\
\text { chlorantraniliprole }\end{array}$ & $80 \mathrm{ml}$ & $89.36 \pm 0.22^{\mathrm{a}}$ & $88.39 \pm 0.93^{\mathrm{a}}$ & $53.37 \pm 0.88^{b}$ \\
\hline Fipronil & Fipronil & $480 \mathrm{ml}$ & $54.24 \pm 1.18^{\mathrm{e}}$ & $52.07 \pm 0.67^{\mathrm{f}}$ & $21.38 \pm 0.44^{\mathrm{d}}$ \\
\hline Emamectin 1.9 EC & Emamectin benzoate & $200 \mathrm{ml}$ & $60.62 \pm 0.91^{\mathrm{d}}$ & $78.34 \pm 2.28^{\mathrm{cd}}$ & $48.03 \pm 1.00^{\mathrm{bc}}$ \\
\hline Chlorofenapyr & Pirate & $320 \mathrm{ml}$ & $69.69 \pm 0.80^{\mathrm{c}}$ & $60.66 \pm 2.46^{\mathrm{e}}$ & $27.32 \pm 0.16^{\mathrm{d}}$ \\
\hline \multirow[t]{4}{*}{ Lufenuron 5 EC } & Lufenuron & $800 \mathrm{ml}$ & $56.02 \pm 0.11^{\mathrm{de}}$ & $57.32 \pm 1.93^{\mathrm{ef}}$ & $25.31 \pm 0.56^{\mathrm{d}}$ \\
\hline & Control & & $4.09 \pm 0.10^{\mathrm{f}}$ & $5.01 \pm 0.83$ & $4.50 \pm 0.21^{\mathrm{e}}$ \\
\hline & Tukey HSD@5\% & & 5.06 & 5.98 & 6.43 \\
\hline & F-value & & 574.61 & 444.15 & 195.14 \\
\hline
\end{tabular}

Means sharing similar letters are not significantly different by Tukey HSD Test at $\mathrm{P}=0.05$; HSD $=$ Honestly Significant Difference; Value * $=$ Significant at $\mathrm{P} \leq 0.05 ; * *=$ Significant at $\mathrm{P} \leq 0.01$.

Table 4. Comparisons of treatments regarding average population of larvae on 15 tomato plants per treatment and percent quantitative yield loss in each treatment.

\begin{tabular}{|c|c|c|c|c|c|}
\hline $\begin{array}{l}\text { Treatment } \\
\text { No. }\end{array}$ & Description of treatments & $\begin{array}{l}\text { Mean damaged fruits on } \\
15 \text { plants/treatment }\end{array}$ & $\begin{array}{l}\text { Mean } \% \text { loss of } \\
\text { yield } / \text { treatment }\end{array}$ & $\begin{array}{l}\text { Oral MT mg/ml } \\
\text { per Kg BW }\end{array}$ & $\begin{array}{l}\text { Dermal MT mg/ml } \\
\text { per Kg BW }\end{array}$ \\
\hline 10 & Control & $6.67^{\mathrm{a}}$ & $23.41^{\mathrm{a}}$ & 0 & 0 \\
\hline 8 & Chlorfenapyre & $6.0^{\mathrm{b}}$ & $18.01^{\mathrm{b}}$ & 560 & $>2000$ \\
\hline 9 & Lufenuron & $5.33^{\mathrm{ab}}$ & $19.80^{\mathrm{ab}}$ & $>2000$ & $>2000$ \\
\hline 5 & $\begin{array}{l}\text { Thiamethaxim }+ \\
\text { chlorantraniliprole }\end{array}$ & $4.33^{\mathrm{abc}}$ & $19.21^{\mathrm{ab}}$ & $>5000+>5000$ & $>2000+>5000$ \\
\hline 7 & Emamectin benzoate & $2.67^{\mathrm{abc}}$ & $13.16^{\mathrm{ab}}$ & $>2950$ & $>2000$ \\
\hline 6 & Fipronil & $2.33^{\mathrm{abc}}$ & $9.98^{\mathrm{ab}}$ & 500 & 2000 \\
\hline 4 & Spintoram & $1.33^{\mathrm{bc}}$ & $8.15^{\mathrm{ab}}$ & $>5000$ & $>5000$ \\
\hline 2 & Indoxacarb & $1.00^{\mathrm{bc}}$ & $4.86^{\mathrm{b}}$ & $>1867$ & $>5000$ \\
\hline 3 & Flubendiamide & $1.00^{\mathrm{bc}}$ & $4.63^{\mathrm{b}}$ & $>2000$ & $>4000$ \\
\hline 1 & Chlorantraniliprole & $0.67^{\mathrm{c}}$ & $3.42^{\mathrm{b}}$ & $>5000$ & $>5000$ \\
\hline
\end{tabular}

$\mathrm{MT}=$ Mammalian Toxicity; BW = Body weight ([11]); Means sharing similar letters are not significantly different by Tukey HSD Test at P $=0.05$; $\mathrm{HSD}=$ Honestly Significant Difference; Value $*=$ Significant at $\mathrm{P} \leq 0.05$. 


\section{Discussion}

The perusal of the results reveal that that after four days of the application, Thiamethaxim + chlorantraniliprole and Spintoram have performed better and these products have maintained their position up till 10 days after application of pesticides. It shows that these products have relatively better persistence and contact mortality of the pest. Whereas, the results on the basis of damaged fruits and percent loss of yield point out that Chlorantraniliprole, Flubendiamide and Indoxacarbhave resulted better as compared to others although the difference is statistically non significant, that these products are relatively fast in action and may have caused the mortality of pest earlier therefore the damage stopped but after four days other products proved even more effective then these one but since there is a non significant difference so the result of above mentioned five pesticides as well as flubemdiamide are almost at par. The results of flubendiamide against the pest are confirmation of results shared by [8].

A limited information is available regarding the efficacy of new chemistry on tomato anyhow, the results of this study are in conformity with [9] who reported that indaxacarb when tested with some other biopesticides reduced the population of Helicoverpa armigera (Hubner) from 10.75 to 0.75 after 1 spray and it was rapid in action. has also reported similar results rather better in view of being ecofriendly, this product also fell on our criteria but unfortunately it could not be tested in this study. [9] had included endosulfan and other products but these products do not fit on our criteria because as a general perception pesticides of Chlorinated Hydrocarbons (CHC) and organophosphates (OP) are more Hazardous to humans as compared to new chemistry. For example acute oral toxicity of endoslfan, chlorpyriphos and profenophos which were conventionally used against this pest is $160 \mathrm{mg}, 96-270 \mathrm{mg}$ and 358 respectively but the acute oral toxicity of the pesticides we have tested are usually more than $>2000$ except fipronil and indaxacarb, see Table 4.

\section{Conclusion}

It can be concluded from this study that Thiamethaxim + chlorantraniliprole, Spintoram, Chlorantraniliprole, Flubendiamide and Indoxacarb are effective and relatively safer choices for control of tomato fruit borer Helicoverpa armigera (Hubner). If the crop is infested and is to be managed, these pesticides can be recommended at proper doses. But if the crop has pest population below economic threshold and further protection from pest is needed, Lufenuron and emamectin can also be used. It is strongly recommended that using conventional pesticides from CHC and OP group should be discouraged for management of Helicoverpa armigera (Hubner), at least on vegetables. The study will serve a step towards modern agriculture, like organic farming [10], for general farming community with an aim to provide the working labor and consumers much safer products.

\section{Acknowledgements}

The authors are thankful to Malik Muhammad Fiaz, Director General, PWQCP, Punjab for his continuous encouragement and demand for research work. Thanks are also due to trainee students Mr. Umer Mushtaq, Mr. Muhammad Zubair Ch., Mr. Mubasher Ahmad and Mr. Malik Muhammad Shahbaz Sharif, students department of Agri Entomology, University of Agriculture, Faissalabad for their help in collection of data and literature during their training over here.

\section{References}

[1] Talekar, N.S., Opena, R.T. and Hanson, P. (2006) H. armigera Management: A Review of AVRDC's Research on Host Plant Resistance in Tomato. Crop Protection, 5, 461-467. http://dx.doi.org/10.1016/j.cropro.2005.07.011

[2] Sharma, H.C. (2001) Cotton Bollworm/Legume Pod Borer, Helicoverpa armigera (Hubner) (Noctuidae: Lepidoptera): Biology and Management. Crop Protec. Compend. CAB Int'l., Wallingford, 70 p.

[3] Latif, M., Aheer, G.M. and Saeed, M. (1997) Quantitative Losses in Tomato Fruits By Helicoverpa armigera Hb. Abstract No. PM-9, 3rd International Congress of Entomological Scientists, Islamabad, 18-20 March 1997, 95 p.

[4] Inayatullah, M. (2007) Biological Control of Tomato Fruitworm (Helicoverpa armigera) Using Egg Parasitoid Trichogramma Chilonis (Trichogrammatidae: Hymenoptera) and Chrysoperla carnea (Chrysopidae: Neuroptera). First Annual Technical Report, HEC Funded Project, 99 p.

[5] Shaheen, N. (2008) Is Organic Forming Suitable Solution For Pakistan. SDPI Research \& News Bulletin, $15,78-81$.

[6] Ignacimuthu, S. (2007) Insect Pest Management. Meeting Report. Current Science, 92, 1336-1337. 
[7] Anon (2014) An Online Information.

http://www.distancesfrom.com/pk/Bahawalpur-city-latitude-longitude-Bahawalpur-city-latitude-Bahawalpur-city-longi tude/LatLongHistory/348522.aspx

[8] Tatagar, M.H., Mohankumar, H.D., Shivaprasad, M. and Mesta, R.K. (2009) Bio-Efficacy of Flubendamide 20 WG Against Chilli Fruit Borer Helicoverpa armigera (Hub.) and Spodoptera litura (Fb.). Karnataka Journal of Agricultural Sciences, 22, 579-581.

[9] Ravi, M., Santharam, G. and Sathiah, N. (2008) Ecofriendly Management of Tomato Fruit Borer Helicoverpa armigera (Hubner). Journal of Biopesticides, 1, 134-138.

[10] Infonet (2014) Losses by Helicoverpa armigera. http://www.infonet-biovision.org/default/ct/113/crops accessed on 22-7-2014

[11] Kard, B., Shelton, K. and Luper, C. (2014) Pesticide Applicator Certification Series Toxicity of Pesticides, Oklahama Cooperative Extension Services, EPP-7457. Oklahoma State University, Oklahoma, USA. http://osufacts.okstate.edu 
Scientific Research Publishing (SCIRP) is one of the largest Open Access journal publishers. It is currently publishing more than 200 open access, online, peer-reviewed journals covering a wide range of academic disciplines. SCIRP serves the worldwide academic communities and contributes to the progress and application of science with its publication.

Other selected journals from SCIRP are listed as below. Submit your manuscript to us via either submit@scirp.org or Online Submission Portal.
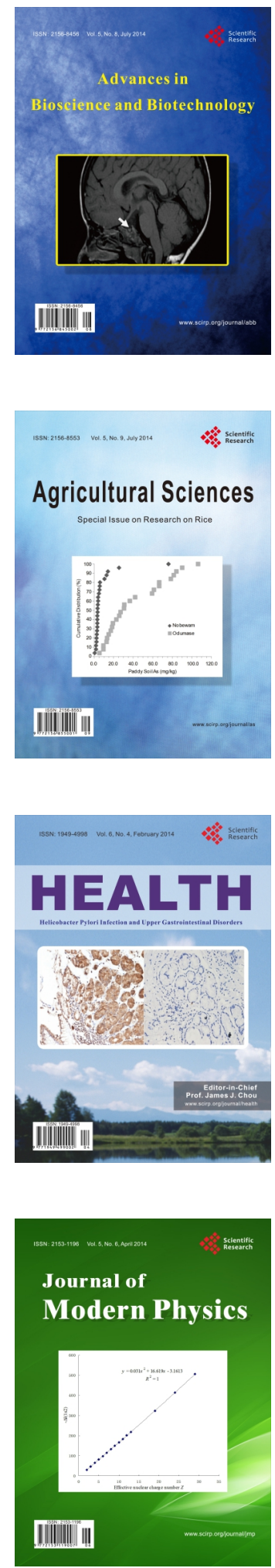
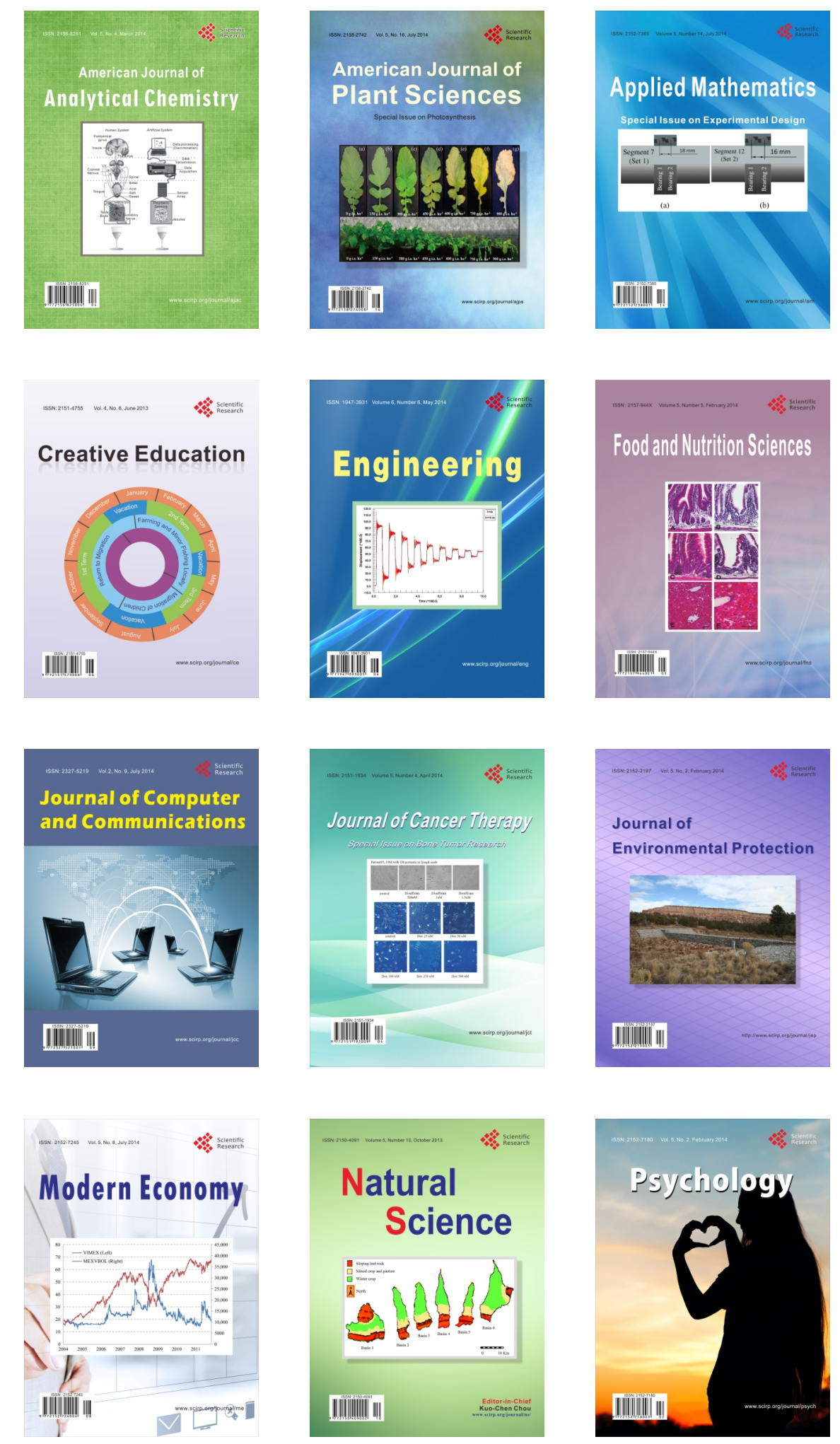